\title{
Potentials Possessed by Mechanical Technology Education Final Year Undergraduate Students of Universities for Self-Employment
}

\author{
Oguejiofor Victor Ikechukwu \\ Department of Mechanical Engineering, University of Nigeria, Nsukka \\ Ezeama Anthony Osita \\ Department of Mechatronic Engineering, University of Nigeria, Nsukka
}

\begin{abstract}
The study was conducted to determine the potentials possessed by mechanical technology education final year undergraduate students of Universities in Enugu State of Nigeria for self-employment in terms of theory, practice and entrepreneurship potentials. The population for the study was 103 people made up of 90 undergraduate students and 13 lectures. The instrument for data collection was structured questionnaire. The return rate of the instrument was $98 \%$. Three experts validated the instruments. A pilot study of five lecturers and 15 undergraduate students were conducted. Cronbach Alpha technique was used to test for the reliability. The total reliability coefficient of .77 was obtained for the instrument. Three research questions and three null hypotheses guided the study. Mean and standard deviation were used to answer the research questions, while ttest was employed to test the null hypotheses at .05 level of significance. The major findings were:(1) that mechanical technology education final year undergraduate students were competent in theoretical knowledge, practical, and entrepreneurship skills but they are incompetent to secure good infrastructures for selfemployment.(2)there was no significant difference between the mean responses of final year undergraduate students of mechanical technology education of Universities and their lecturers on the theoretical knowledge, practical and entrepreneurship skills they possessed for self- employment. It was recommended that Universities should be well equipped with competent mechanical technology education lecturers, technologist and functional workshop and equipment in other to enhance the teaching and learning of mechanical technology education and inculcate in their curriculum fund raising for self-employment.
\end{abstract}

Keywords: Self-employment, potentials, mechanical technology

DOI: $10.7176 / \mathrm{JEP} / 10-36-08$

Publication date: December $31^{\text {st }} 2019$

\section{Introduction}

One of the biggest challenges of the economy of any nation is providing employment for its citizens. Many nations have fewer available jobs compared to the number of prospective applicants. Many are characterized by mass unemployment and they are in serious trouble. In Nigeria and Enugu State in particular, the growing problem of unemployment has contributed largely to the worsening problem of poverty among the populace (Economy watch, 2010). Unemployment, according to Olaitan (2011), leads to frustration and disillusionment which may result in crime or drug abuse in a futile attempt to escape from and forget the pains and humiliation of poverty. The problem of unemployment has worsened as millions of graduates have not secured gainful employment over the years (Howell, 2012). Fajana (2010) stated that the cause of unemployment in Nigeria included: technological underdevelopment, defective human resources planning, lack of industrialization, and lack of adequate labour market information, government insensitivity to the needs of the teaming youths, bad leadership and government policies, crime and corruption.

Mechanical technology education has the ability to develop human resources that would improve industrialization and thereby enhance the economy (Robertson, 2010). Uzodinma and Obayi (2015) defined technical education as education that makes one earn a living in an occupation which success is dependent largely in technical information, principles of technology as applied to modern design, production, distribution and service. Technology education is one of the greatest agents directly responsible for the development of technological human resources in Nigeria which can generate employment and reduce poverty.

Mechanical technology education is education for economic development and self reliance. (Mucculloch, 2011). Elobuike (2010) identified mechanical technology education as a branch of education that is concerned with the development of competent workers in terms of acquisition of adequate knowledge and technical skills. It helps to create jobs and reduce unemployment, underdevelopment and misemployment. It gives adequate training and education to the youths and adults and enables them to acquire skills necessary for success in a chosen career. Onoh (2011) showed that mechanical technology education was formed in the concept of traditional apprenticeship training. 
The students of mechanical technology education are expected to go into successful self employment on graduation because they have passed through formal institutions and have acquired better coordinated knowledge and skills needed on the job. Mechanical technology education equips the students with the potentials that cover theory, practical and entrepreneurship skills in mechanical technology which enable them, go into selfemployment, wealth and job creations. Mechanical technology education is a planned and coordinated educational programme with the aim to produce technological human resources that would exploit the natural resources of the country for economic development (Mucculloch, 2011). The basic function of technology education is to prepare people for employment. Creative and innovative minds use the knowledge acquired during technical training to tap the national resource and create employment for themselves and others through the potential they acquired during their technical training.

According to Webster (2013) 'potential' means a quality that something has that can be developed to make it better. It is ability that somebody has that can be developed to help that person become successful. It is the latent qualities that may be developed and lead to future success. Potential can be latent, dormant or quiescent. (Collins, 2011). Latent means present or in existence but not active or manifest. It is present but not visible. Latent means hidden. Dormant evokes the idea of sleep. Quiescent means inactive. Potential can help in developing employable qualities on students.

Elobuike (2010) pointed out that mechanical technology education develops employable and saleable qualities in her products to enable them secure and succeed in an employment. When the requirements for selfemployment are properly articulated and harnessed, the problem of unemployment will be drastically reduced. Then poverty will be alleviated. It is against this background that this study is being undertaken to address the potentials possessed by mechanical technology education final year undergraduate students of the Universities for self employment. Uzoagulu (2011) opined that students of mechanical technology education could overcome problem of unemployment, if they could live up to the training they received which provide them with theory, practice and entrepreneurship competencies.

The concern of this study is that mechanical technology education undergraduate students of Universities might not possess the potentials for self employed, given the reality of jobs in public and private sectors. Many students after graduation stayed unemployed for some years despite the technical and self-reliance oriented training that they received. It seems that they lack the potentials necessary for self-employment which are in terms of adequate theoretical knowledge, practical skills and entrepreneurship skills. The problem of the study therefore is; what are potentials possessed by mechanical technology education undergraduate students of Universities for self employment.

The purpose of the study was to determine the potentials possessed by mechanical technology education final year undergraduate students of Universities for self-employment. Specifically, the study sought to:

1. determine the extent to which mechanical technology education undergraduate students of Universities possess theoretical knowledge for self-employment.

2. determine the extent to which mechanical technology education undergraduate students of Universities possess practical skills for self- employment.

3. determine the entrepreneurship competencies possessed by mechanical technology education undergraduate Students of Universities for self- employment.

\section{Research Questions}

The following research questions guided the study.

1. To what extent do the final year undergraduate students of mechanical technology education of Universities possess adequate theoretical knowledge for self- employment?

2. To what extent do the final year undergraduate students of mechanical technology education of Universities possess adequate practical skills for self- employment?

3. To what extent do the final year undergraduate students of mechanical technology education of Universities possess entrepreneurship skills for self- employment?

\section{Null Hypotheses}

The following null hypotheses were tested at .05 level of significant.

H01: There is no significant difference between the mean responses of final year undergraduate students of mechanical technology education of Universities and their lecturers on the theoretical knowledge they possessed for self- employment.

H02: A significant difference does not exist between the mean responses of the final year undergraduate students of mechanical technology education of Universities and their lecturers on the practical skills they possessed for self- employment.

H03: A significant difference does not exist between the mean responses of the final year undergraduate students of mechanical technology education of Universities and their lecturers on the entrepreneurship 
skills they possessed for self- employment.

\section{Method}

The research was survey research design. This was in line with Osuala (2009) who opined that a survey research design is one in which a group of people or items are studied by collecting and analyzing data from a few people or items considered to be representative of the entire population. The study was conducted in the Universities in Enugu State of Nigeria that run mechanical technology education programmes. Enugu State, is located on the latitude of $6^{0} 30$ North and on the longitude of $7^{0} 30$ East.

The population for the study was 103 respondents, comprised of 90 final year undergraduate students of mechanical technology education and 13 lecturers from University of Nigeria, Nsukka and Enugu State University of Science and Technology, Enugu. The population identified for the study was not too large; therefore, the entire population was used for the study. There was no sampling. The instrument for data collection was a structured questionnaire developed by the researcher using a four point responses scale of very great extent (4), great extent (3), low extent (2) and very low extent (1). The instrument was validated by three experts and its reliability $(\mathrm{r}=0.77)$ coefficient was established using Cronbach Alpha measure of internal consistency. The instrument was administered by hand with the aid two research assistants. The return rate was $98 \%$. Mean and standard deviation were used to answer the three research questions, while t-test statistic was used to test the null hypotheses at 0.05 level of significance.

\section{Result}

Data collected for the study were analyzed and presented based on the research questions and hypotheses that guided the study. The details are contained in the tables $1-6$.

\section{Research Question 1}

To what extent do undergraduate students of mechanical technology education of Universities possess adequate theoretical knowledge for self- employment?

Table 1

Mean Ratings of Theoretical Knowledge Possessed by Undergraduate Students of Mechanical Technology Education of Universities for Self-employment.

\begin{tabular}{|c|c|c|c|c|c|c|c|}
\hline \multirow[t]{2}{*}{$\mathbf{S} / \mathbf{N}$} & \multirow[t]{2}{*}{ Item statement } & \multicolumn{2}{|c|}{$\mathbf{X}$} & \multicolumn{2}{|c|}{ SD } & \multicolumn{2}{|c|}{ Decision } \\
\hline & & $\mathrm{L}$ & US & $\mathrm{L}$ & US & $\mathrm{L}$ & US \\
\hline 1 & Communicate effectively in written English & 3.69 & 3.58 & 0.62 & 0.66 & GE & $\mathrm{GE}$ \\
\hline 2 & Communicate very well in spoken English & 3.69 & 3.50 & 0.62 & 0.77 & GE & GE \\
\hline 3 & $\begin{array}{l}\text { Understand workshop management in Mechanical Technology } \\
\text { Education }\end{array}$ & 3.10 & 2.96 & 0.49 & 0.47 & GE & \\
\hline 4 & $\begin{array}{l}\text { Adequately explain entrepreneurship studies in Mechanical } \\
\text { Technology Education }\end{array}$ & 3.20 & 3.20 & 0.72 & 0.62 & GE & GE \\
\hline 5 & Understand safety regulation in the workshop & 2.90 & 3.59 & 0.45 & 0.92 & GE & GE \\
\hline 6 & $\begin{array}{l}\text { Understand the science applicable in Mechanical Technology } \\
\text { Education }\end{array}$ & 2.90 & 2.90 & 0.49 & 0.63 & GE & GE \\
\hline 7 & $\begin{array}{l}\text { Understand the concept of drafting and design in Mechanical } \\
\text { Technology Education }\end{array}$ & 3.20 & 3.28 & 0.80 & 0.65 & GE & $\mathrm{GE}$ \\
\hline 8 & Understand the use of equipment & 2.77 & 2.77 & 0.52 & 0.57 & GE & GE \\
\hline & Grand mean & 3.18 & 3.22 & 0.59 & 0.66 & GE & GE \\
\hline
\end{tabular}

The data presented in Table 1 showed that the respondents agreed to great extent (GE) that all the items indentified are the theoretical knowledge potential possessed by final year undergraduate students of mechanical technology education of Universities for self-employment. The mean values were above the bench mark of 2.50 and the grand means of the two groups of respondent were also above 2.50 .

\section{Null Hypotheses One}

There is no significant difference between the mean responses of final year undergraduate students of mechanical technology education of Universities and their lecturers on the theoretical knowledge they possessed for self- employment. 
Table 2

t-test of difference between the Mean Rating of final year Undergraduate Students of Mechanical Technology Education and their Lectures on the Theoretical Knowledge they Possessed for Selfemployment

\begin{tabular}{llllllll}
\hline Respondent & N & $\bar{X}$ & SD & Df & t-cal & t-crit & Decision \\
\hline Lecturers & 13 & 3.22 & 0.59 & 101 & 1.18 & \pm 1.96 & NS \\
Undergraduate students & 90 & 3.18 & 0.66 & & & & \\
\hline
\end{tabular}

Note: $N=$ number of respondents, $\overline{\mathrm{X}}=$ mean, $S D=$ standard deviation and $N S=$ Not Significant

The data in Table 2 showed that $t$-calculated of 1.18 is less than t-critical (1.96) therefore, there is no significant different between the mean responses of final year undergraduate students of mechanical technology education and their lectures on the theoretical knowledge they possessed for self-employment.

\section{Research Question Two}

To what extent do the final year undergraduate students of mechanical technology education of Universities possess adequate practical skills for self- employment?

Table 3

Mean Ratings of Practical Skills Potentials Possessed by final year Undergraduate Students of Mechanical Technology Education of Universities for Self-employment.

\begin{tabular}{|c|c|c|c|c|c|c|c|}
\hline \multirow[t]{2}{*}{$\mathbf{S} / \mathbf{N}$} & & \multicolumn{2}{|c|}{$\mathbf{X}$} & \multicolumn{2}{|c|}{ SD } & \multicolumn{2}{|c|}{ Decision } \\
\hline & & $\mathbf{L}$ & US & $\mathbf{L}$ & US & $\mathbf{L}$ & US \\
\hline 9 & Use of measuring instruments & 3.20 & 3.16 & 0.45 & 0.66 & GE & GE \\
\hline 10 & Servicing of power tools & 2.77 & 2.54 & 1.25 & 0.69 & GE & GE \\
\hline 11 & Appropriate use of hand tools & 3.20 & 3.20 & 0.45 & 0.69 & GE & GE \\
\hline 12 & Appropriate use of machine tools & 3.77 & 3.70 & 0.43 & 0.61 & GE & GE \\
\hline 13 & Ability to finished work according to standard & 2.90 & 2.60 & 0.57 & 0.54 & GE & GE \\
\hline 14 & $\begin{array}{l}\text { Correct interpretation and application of mechanical } \\
\text { blue print working drawing }\end{array}$ & 3.10 & 3.39 & 0.88 & 1.25 & GE & GE \\
\hline 15 & Correct use of manufacturers manual for repairs & 3.10 & 2.77 & 0.49 & 0.77 & GE & GE \\
\hline 16 & Ability to keep equipment clean after use & 3.69 & 3.76 & 0.62 & 0.48 & GE & GE \\
\hline 17 & Identification of various mechanical components & 3.77 & 3.30 & 0.45 & 0.73 & GE & GE \\
\hline 18 & $\begin{array}{l}\text { Use of maintenance schedules of various workshop } \\
\text { machineries }\end{array}$ & 3.77 & 3.60 & 0.45 & 0.62 & GE & GE \\
\hline 19 & Rectification of faculty equipment & 2.90 & 2.40 & 0.49 & 0.31 & GE & LE \\
\hline 20 & Correct use of safety wears & 3.77 & 3.70 & 0.45 & 0.56 & GE & GE \\
\hline & Grand Mean & 3.33 & 3.18 & 0.58 & 0.66 & GE & GE \\
\hline
\end{tabular}

Note: $L=$ Lecturers $=13$, US $=$ Undergraduate students $=90, X=$ Mean and $S D=$ Standard deviation

Data in Table 3 showed that the respondent has high mean ratings for all the items for the practical skills potentials possessed by final year undergraduate students of mechanical technology education of Universities for self-employment. The mean values and the grand mean for the two groups of the respondents were above the bench mark of 2.50 .

\section{Null Hypotheses Two}

A significant difference does not exist between the mean responses of the final year undergraduate students of mechanical technology education of the Universities and their lecturers on the practical skills they possessed for self- employment.

Table 4

t-test of differences between the Mean Rating of final year Undergraduate Students of Mechanical Technology Education and their Lecturers on the Practical Skills they Possessed for Self-employment

\begin{tabular}{llllllll}
\hline Respondent & $\mathrm{N}$ & $\overline{\mathrm{X}}$ & $\mathrm{SD}$ & $\mathrm{Df}$ & t-cal & t-crit & Decision \\
\hline Lecturers & 13 & 3.30 & 0.56 & 101 & 0.88 & \pm 1.96 & NS \\
Undergraduate students & 90 & 3.16 & 0.66 & & & & \\
\hline
\end{tabular}

Note: $N=$ number of respondents, $\overline{\mathrm{X}}=$ mean, $S D=$ standard deviation and $N S=$ Not Significant

The data in Table 4 showed that t-calculated of 0.88 is less that t-critical which is 1.96 , therefore a significant difference does not exist between the mean responses of final year undergraduate students of mechanical technology education of the Universities and their lecturers on the practical skills they possessed for self- employment. 


\section{Research Question Three}

To what extent do the final year undergraduate students of mechanical technology education of Universities possess entrepreneurship skills for self- employment?

Table 5

Mean Ratings of Entrepreneurship Skills Possessed by final year Undergraduate Students Mechanical Technology Education of Universities for Self-employment

\begin{tabular}{|c|c|c|c|c|c|c|c|}
\hline \multirow[t]{2}{*}{$\mathbf{S} / \mathbf{N}$} & \multirow[t]{2}{*}{ Item statement } & \multicolumn{2}{|l|}{$\mathbf{X}$} & \multicolumn{2}{|c|}{ SD } & \multicolumn{2}{|c|}{ Decision } \\
\hline & & $\mathbf{L}$ & US & $\mathbf{L}$ & US & $\mathbf{L}$ & US \\
\hline 21 & Desire to achieve & 2.90 & 2.50 & 0.49 & 0.57 & GE & GE \\
\hline 22 & Drive for independence & 3.69 & 3.10 & 0.62 & 0.59 & GE & GE \\
\hline 23 & Identifying exploitable business opportunity & 3.00 & 2.90 & 0.91 & 0.78 & GE & GE \\
\hline 24 & Drawing a comprehensive business plan & 3.10 & 3.37 & 0.62 & 0.62 & GE & GE \\
\hline 25 & Accountability & 3.60 & 2.99 & 0.77 & 0.68 & GE & GE \\
\hline 26 & Ability to be focus & 3.70 & 2.85 & 0.62 & 0.61 & GE & GE \\
\hline 27 & Ability to separate self from business & 3.10 & 2.98 & 0.49 & 0.84 & GE & GE \\
\hline 28 & Ability to work with a team & 2.90 & 2.58 & 0.49 & 0.69 & GE & GE \\
\hline 29 & Exhibit managerial skill in adequate measure & 3.80 & 2.80 & 0.44 & 0.69 & GE & GE \\
\hline 30 & Securing of good infrastructures & 1.90 & 1.80 & 0.95 & 0.71 & LE & $\mathrm{LE}$ \\
\hline 31 & Good display of innovation & 3.10 & 2.80 & 0.49 & 0.66 & GE & GE \\
\hline 32 & Ability to be initiative & 3.10 & 3.00 & 0.49 & 0.67 & GE & GE \\
\hline 33 & Effective record keeping & 3.70 & 3.60 & 0.62 & 0.78 & GE & GE \\
\hline 34 & Effective human / public relation qualities & 3.77 & 3.00 & 0.44 & 0.67 & GE & GE \\
\hline \multirow[t]{2}{*}{35} & Drive for hard work & 3.69 & 3.30 & 0.62 & 0.82 & GE & GE \\
\hline & Grand mean & 3.27 & 3.01 & 0.60 & 0.65 & GE & GE \\
\hline
\end{tabular}

Note: $L=$ Lecturers $=13$, US $=$ Undergraduate students $=90, X=$ Mean and $S D=$ Standard deviation

The data presented in table 5, shows that the respondents had high mean ratings for 14 items and a low mean rating for 1 item. The grand means were 3.27 and 3.00 respectively, indicating that mechanical technology education final year undergraduate students of Universities in Enugu State possessed entrepreneurship potential for self-employment to a great extent, but their ability to secure good infrastructures for self-employment was low.

\section{Null Hypotheses Three}

A significant difference does not exist between the mean responses of the final year undergraduate students of mechanical technology education of Universities and their lecturers on the entrepreneurship skills they possessed for self- employment.

\section{Table 6}

t-test of difference between the Mean Rating of final year Undergraduate Students of Mechanical Technology Education of Universities and their Lecturers on the Entrepreneurship Skills they possessed for Self-employment.

\begin{tabular}{llllllll}
\hline Respondent & $\mathrm{N}$ & $\overline{\mathrm{X}}$ & $\mathrm{SD}$ & $\mathrm{Df}$ & $\mathrm{t}$-cal & t-crit & Decision \\
\hline Lecturers & 13 & 3.27 & 0.60 & 101 & 1.44 & \pm 1.96 & NS \\
Undergraduate students & 90 & 2.90 & 0.64 & & & & \\
\hline
\end{tabular}

Note: $N=$ number of respondents, $\overline{\mathrm{X}}=$ mean, $S D=$ standard deviation and $N S=$ Not Significant

The data in Table 6 showed that t- calculated of 1.44 is less than t-critical which is 1.96 , therefore there is no significant differences between the mean responses of final year undergraduate students of mechanical technology education of Universities and their lecturers on the entrepreneurship skills the possessed for selfemployment.

\section{Discussion of Findings}

The analysis of respondents to all the research questions revealed that 49 items out of the 50 items listed had mean ratings that qualify them as the potentials possessed by final year undergraduate students of Mechanical Technology Education of Universities for self-employment. The 49 items had a mean value that is above the benchmark of 2.50 and one item has mean value of 1.85 .

The grand mean $(\mathrm{x})$ for the two groups of the respondents in all the research questions were above 2.50, showing that final year undergraduate students of Mechanical Technology Education of Universities possessed potentials for self-employment but the lack ability in securing good infrastructure. The closeness of the responses as shown by the entire standard deviation (SD) indicates homogeneity in their responses. Testing of the three hypotheses as shown in tables 2, 4 and 6 revealed that the t-calculated in all the hypotheses were less 
than t-critical. This shows that there is no significant difference between the mean responses of final year undergraduate students of mechanical technology education of Universities and their lecturers on the theoretical knowledge, practical, and entrepreneurship skills they possessed for self- employment

\section{Conclusion}

Final year undergraduate students of mechanical technology education of Universities in Enugu State on graduation possessed some potential for self- employment. This assertion was affirmed by the findings of the study, which showed that mechanical technology education undergraduate students exhibited to a great extent theoretical knowledge, practical and entrepreneurship skills for self- employment. However, the result of this study further indicated that they lack ability in the area of securing good infrastructure for self-employment.

\section{Recommendations}

Based on the result of this study, the following recommendations were made:

1. Universities should be well equipped with competent mechanical technology education lectures, technologist and functional workshop equipment in other to enhance the teaching and learning of mechanical technology education.

2. The education policy makers and educational institutions should make sure that undergraduate students of mechanical technology education are given sound entrepreneurship training so that they can be job creator on graduation.

3. Governments should assist final year undergraduate students of mechanical technology education to establishing their own enterprise on graduation.

\section{References}

Butter, B. (2013). The Creation of a Company Culture. London: Oxford University press.

Collins, H. (2011). Collins English Dictionary. UK: HarperCollins Publishers Ltd.

Economy watch (2010) Retrieve on 12/01/2014 from http:www/economy.watch.com

Elobuike, H.U. (2010). Curriculum Development in Technology and Vocational Education. Enugu: Cheston press ltd.

Fajana, S. (2010). Functionary of Nigerian labour market. Lagos: labofin and co.

Federal Ministry of Education (2014). The National Policy on Education (reversed), Lagos: Federal Government. Howell, W. (2012). The Encyclopedia of Education. Chicago: Standard Education co-operatives.

Hoyt, K.B. (2010). What the future holds for vocational education. Onitsha: summer Educational publishing Nigeria ltd.

Kayode, A. (2013). Global Finical Crisis and Economic Development in Nigeria: The change of Vision 20:20:20. Journal of Economic and Sustainable Development 4(4) 41

Muculloch, R.E. (2011). Nature and Causes of Unemployment. New York: Harper and Row Publishers.

National Bureau of Statistics (2012). National Bureau of Statistics Annual Report, Lagos: Government Press.

Olaitian S.O. (2011). Practical research methods in education. Onitsha; Summer Educational Publishers.

Onoh, B.C.E.C. (2011). Fundamental of Entrepreneurship Studies. Nigeria Cheston agency press ltd.

Osuala, E.C. (2009). Foundation of Vocational Education. Nsukka: Fulladu Publishers co.

Robertson, E.M. (2010). Cause of Unemployment in Nigeria. UK: The British Press.

Uzoagulu, A.E. (2011). Practical guide to writing research project reports in tertiary institution. Nigeria; Cheston Agency Press ltd.

Uzodinma, C.U. and Obayi, T.U. (2015). The economics of vocational and technical education for Nigeria. Enugu: Bob Billion publishers.

Webster, N. (2013). New standard Encyclopedia. Chicago: Standard education co-operative 